\title{
UPTAKE AND TRANSLOCATION OF NITROGEN, PHOSPHORUS AND CALCIUM IN SOYBEAN INFECTED WITH Meloidogyne incognita AND M. javanica
}

\author{
RUI G. CARNEIRO ${ }^{1}$, PAULO MAZZAFERA ${ }^{2}$, LUIZ CARLOS C.B. FERRAZ ${ }^{3}$, \\ TAKASHI MURAOKA ${ }^{4} \&$ PAULO CESAR O. TRIVELIN 5
}

\begin{abstract}
${ }^{1}$ Instituto Agronômico do Paraná, Cx. Postal 481, 86001-970, Londrina, PR, Brazil; ${ }^{2}$ Departamento de Fisiologia Vegetal, Instituto de Biologia, Cx. Postal 6109, Universidade Estadual de Campinas, 13083-970, Campinas, SP, Brazil, fax: 0193289 3124, e-mail: pmazza@obelix.unicamp.br; ${ }^{3}$ Departamento de Entomologia, Fitopatologia e Zoologia Agrícola, ESALQ-USP, Cx. Postal 9, 13418-900, Piracicaba, Brazil; ${ }^{4}$ Laboratório de Fertilidade do Solo; ${ }^{5}$ Laboratório de Isótopos Estáveis, CENA-USP, Piracicaba, SP, Brazil
\end{abstract}

(Aceito para publicação em 03/09/2001)

Autor para correspondência: Paulo Mazzafera

CARNEIRO, R.G., MAZZAFERA, P., FERRAZ, L.C.C.B., MURAOKA, T. \& TREVELIN, P.C.O. Uptake and translocation of nitrogen, phosphorus and calcium in soybean infected with Meloidogyne incognita and M. javanica Fitopatologia Brasileira 27:141-150. 2002.

\begin{abstract}
Two soybean (Glycine max) cultivars were used in this study, Ocepar 4, rated as moderately resistant to Meloidogyne incognita race 3 but susceptible to M. javanica, and 'BR 16', susceptible to both nematodes. The effect of nematodes infection on the uptake and transport of N, P and $\mathrm{Ca}$ to the shoot was studied in plants growing in a split root system. The upper half was inoculated with $0,3,000,9,000$ or 27,000 eggs/plant while the lower half received ${ }^{15} \mathrm{~N},{ }^{32} \mathrm{P}$ or ${ }^{45} \mathrm{Ca}$. Infected plants showed an increase of root but a decrease of shoot mass with increasing inoculum levels. In general, total endogenous nutrients increased in the roots and tended to decrease in the shoots with increasing inoculum levels. When concentrations were calculated, there was an increase in the three nutrients in the roots, and an increase of $\mathrm{Ca}$ but no significant variation

of $\mathrm{N}$ and $\mathrm{P}$ was observed in the shoots. The total amount of ${ }^{15} \mathrm{~N}$ in the roots increased at the highest inoculum levels but ${ }^{32} \mathrm{P}$ and ${ }^{45} \mathrm{Ca}$ decreased. In the shoots there was a reduction of ${ }^{32} \mathrm{P}$ and ${ }^{45} \mathrm{Ca}$. The specific concentrations of the labelled nutrients (abundance or radioactivity/ tissue mass) also showed a decrease of ${ }^{32} \mathrm{P}$ and ${ }^{45} \mathrm{Ca}$ in the shoots and roots of infected plants and an increase of ${ }^{15} \mathrm{~N}$ in the shoots. Considering that overall nutrient concentrations reflect cumulative nutrient uptake and the data from labelled elements gave information at a specific moment of the infection, thus nematodes do interfere with nutrient uptake and translocation.

Additional key words: mineral nutrition, nematodes, nutrient uptake.

\section{RESUMO}

\section{Absorção e transporte de nitrogênio, fósforo e cálcio em soja infetada com Meloidogyne incognita e M. javanica}

Duas cultivares de soja (Glycine max) foram usadas neste estudo, Ocepar 4, moderadamente resistente a Meloidogyne incognita raça 3, mas suscetível a $M$. javanica, e 'BR 16', suscetível a ambos nematóides. $\mathrm{O}$ efeito da infecção de nematóides na absorção e transporte de N, P e Ca para a parte aérea foi estudada em plantas crescendo em um sistema da raízes divividas, sendo a parte superior das raízes inoculada com $0,3.000,9.000$ ou 27.000 ovos/planta, enquanto a inferior recebeu ${ }^{15} \mathrm{~N},{ }^{32} \mathrm{P}$ ou ${ }^{45} \mathrm{Ca}$. Plantas infetadas mostraram aumento de raízes, mas diminuição da massa da parte aérea com o aumento do inóculo. De modo geral, as quantidades endógenas totais dos elementos estudados aumentaram nas raízes e tenderam a diminuir na parte aérea com o aumento do inóculo. Quando os dados

foram expressos em concentração do elemento/massa de tecido, observou-se aumento para os três elementos nas raízes e aumento de $\mathrm{Ca}$ na parte aérea. A quantidade total de ${ }^{15} \mathrm{~N}$ nas raízes aumentou no maior nível de inóculo, havendo diminuição de ${ }^{32} \mathrm{P}$ e ${ }^{45} \mathrm{Ca}$. Na parte aérea, houve redução de ${ }^{32} \mathrm{P} \mathrm{e}{ }^{45} \mathrm{Ca}$. As concentrações específicas dos elementos marcados (abundância ou radioatividade/massa de tecido) também mostrou diminuição de ${ }^{32} \mathrm{P} \mathrm{e}{ }^{45} \mathrm{Ca}$ na parte aérea e raízes de plantas infetadas, e aumento de ${ }^{15} \mathrm{~N}$ na parte aérea. Considerando que as quantidades endógenas dos elementos refletem a absorção cumulativa e que os dados de elementos marcados fornecem informação de um momento específico da infecção, nematóides interferem de fato com a absorção e translocação de nutrientes.
\end{abstract}

\section{INTRODUCTION}

Mineral deficiency is a common symptom in plants attacked by root-knot nematodes. Histological studies have shown a disruption of the xylem in Meloidogyne galls as well as the presence of abnormally formed xylem vessels causing the interruption of water transport (Kirkpatrick et al., 1991) and consequently the translocation of absorbed nutrients to the shoot.
The results on the effects of nematodes on nutrient uptake and transport in plants are contradictory. Dropkin \& King (1956) concluded that $\mathrm{P}$ translocation was not affected in tomato (Lycopersicon esculentum L.) plants infected with $M$. incognita (Kofoid et White) Chitwood and that the use of $\mathrm{P}$ by the parasite was no greater than $10 \%$ of the nutrient uptake by the plant. Hunter (1958) observed an increase in P in tomato roots infected by $M$. incognita acrita Chitwood \& Oteifa. Since there was no alteration in the shoot 


\section{R.G. Carneiro et al.}

concentration, the author concluded that the transport of $\mathrm{P}$ was not affected. No alteration was observed with respect to Ca. Oteifa \& Elgindi (1962) observed that in roots of tomato infected with M. javanica (Treub) Chitwood, there was accumulation of ${ }^{32} \mathrm{P}$ and reduction in $\mathrm{P}$ translocation to the shoot. Increase of $\mathrm{N}$ and $\mathrm{P}$ and decrease of $\mathrm{Ca}$ in the roots of Capsicum infected with $M$. incognita acrita was observed by Shafiee \& Jenkins (1963). On the other hand, Jenkins \& Malek (1966) detected increase of $\mathrm{N}$ and decrease of $\mathrm{Ca}$ and $\mathrm{P}$ in the roots of vetch (Vicia villosa Roth) infected with M. hapla Chitwood. In the leaves, they also observed a decrease of $\mathrm{Ca}$ and P, but $\mathrm{N}$ was not altered. Bergeson (1966) studied the mobilization of several minerals in tomato infected with $M$. incognita and concluded that the nematode caused an increase in their concentration in the roots but not in the leaves, indicating that transport to the shoot was not affected. In common bean (Phaseolus vulgaris L.) plants, M. incognita caused reduction of total $\mathrm{N}$ in the whole plant and in the roots, but the total content in the shoots was not changed, although the concentration of $\mathrm{N}$ and $\mathrm{Ca}$ in the roots and shoots had increased (Melakeberhan et al., 1985).

For most of the aforementioned studies, the nutrients, isotopically labelled or not, were supplied by watering infected roots with nutrient solutions. Thus, infected and noninfected roots were considered together in terms of their abilities both to absorb and to translocate nutrients.

The aim of this work was to study uptake and translocation of $\mathrm{N}, \mathrm{P}$ and $\mathrm{Ca}$ in roots of soybean [Glycine $\max ($ L.) Merr.] plants of two cultivars infected with $M$. incognita and $M$. javanica, using a split root system where the nutrients were supplied to roots positioned below those roots infected by nematodes. To demonstrate the effects of nematodes on absorption and translocation of nutrients the evaluations were carried out after a single life cycle of the nematode had been completed, avoiding secondary infections.

\section{MATERIALS AND METHODS}

\section{Plant material, inoculum and nematode reproduction}

Two soybean cultivars were used in this study, Ocepar 4 , rated as moderately resistant to $M$. incognita race 3 but susceptible to $M$. javanica, and BR 16, susceptible to both nematodes (EMBRAPA, 1996). The nematodes were cultured on greenhouse-grown tomato cv. Rutgers. Eggs were extracted from the infected roots according to the method of Hussey \& Barker (1973), except that the galled roots were cut into pieces and processed in a mechanical blender containing a $0.5 \%$ $\mathrm{NaOCl}$ solution for $20 \mathrm{sec}$, according to an alternative protocol proposed by Boneti \& Ferraz (1981).

Nematode reproductive data were obtained by growing plants of both cultivars in $400 \mathrm{~cm}^{3}$ plastic pots filled with an autoclaved mixture of soil and sand $(1: 1, \mathrm{v} / \mathrm{v})$, inoculating with $5 \mathrm{ml}$ of water containing $0,3,000,9,000$, or 27,000 eggs/plant of either $M$. incognita or $M$. javanica, and estimating the number of eggs in the roots after 50 days. Four plants were inoculated for each inoculum level. Eggs were extracted from the roots as described above. This experiment was conducted under greenhouse conditions, the temperature ranging from 18.1 to $29.8{ }^{\circ} \mathrm{C}$.

\section{Feeding plants with ${ }^{15} \mathrm{~N},{ }^{32} \mathrm{P}$ and ${ }^{45} \mathrm{Ca}$}

Three independent experiments were carried out to study the uptake and translocation of N, P and $\mathrm{Ca}$ in infected plants.

Seeds were germinated in plastic pots $\left(400 \mathrm{~cm}^{3}\right)$ containing a mixture of soil and sand $(1: 1, \mathrm{v} / \mathrm{v})$, which was previously autoclaved $\left(120^{\circ} \mathrm{C}, 60 \mathrm{~min}\right)$ and fumigated with methyl bromide $\left(150 \mathrm{~cm}^{3} / \mathrm{m}^{3}\right)$. These pots had the bottom removed and replaced by a net to allow the tap root to grow out of the substrate. To avoid root drying, each plastic pot was placed inside another $\left(200 \mathrm{~cm}^{3}\right)$ partially filled with water. Subsequently, the emerging tap root was cut to break the apical dominance and increase the production of secondary roots, and the plastic pot placed inside another $200 \mathrm{~cm}^{3}$ plastic pot, now filled with vermiculite and perforated at the bottom to allow water to drain. A small space was left between the vermiculite and the bottom of the upper pot. Since the lower pot was not removed until the end of the experiment, the secondary roots were watered via a plastic tube passing through the upper pot. To avoid nematode movement in water draining from the upper to the lower pot, sufficient water was added to the upper pot only to wet the pot for $1 / 3$ to $1 / 2$ of its height. This was possible because the plastic pot had a thin and white wall. During the period that the plants were kept in this system, no wilting was noticed and, at the end of the experiment, there was no obvious contamination of the lower roots by nematodes. For the feeding of the plants with ${ }^{15} \mathrm{~N},{ }^{32} \mathrm{P}$ and ${ }^{45} \mathrm{Ca}$, a third pot $\left(200 \mathrm{~cm}^{3}\right)$ containing the nutrient solutions was placed under the second pot, whose perforated bottom allowed the nutrient solution to come in contact with the roots.

Plant inoculation was carried out on the same day as the tap root was cut (ten days after sowing). The inoculum $(0,3,000,9,000$, or 27,000 eggs/plant) was added after adjusting the egg suspension volume per pot to $5 \mathrm{ml}$. Four replicates were inoculated for each level in each soybean cultivar. The plants were maintained in the greenhouse for 40 days until they received the nutrient solutions. The temperature ranged from 17.6 to $29.8^{\circ} \mathrm{C}$ during this period.

The nutrient solutions were prepared as follows:

${ }^{15} \mathrm{~N}-1.52 \mathrm{~g}$ of $\mathrm{K}^{15} \mathrm{NO}_{3}(11.1 \%$ enriched, Junta de Energia Nuclear - Madrid) was dissolved in $30 \mathrm{ml}$ of $1 / 4$ strength nutrient solution (Hoagland \& Arnon, 1950) prepared without any other form of $\mathrm{N}$. Each plant received this solution at 8:00 a.m. and the roots were collected $24 \mathrm{~h}$ later.

${ }^{32} \mathrm{P}$ - Each plant received $40 \mathrm{ml}$ of a $0.5 \mu \mathrm{M} \mathrm{KH} \mathrm{PO}_{4}$ solution, containing $3.5 \mathrm{MBq}$ of $\mathrm{H}_{3}{ }^{32} \mathrm{PO}_{4}(7.4 \mathrm{GBq} / \mathrm{mmol}$, Amersham). The plants received this solution at 8:00a.m. and the roots were collected $5 \mathrm{~h}$ later.

${ }^{45} \mathrm{Ca}$ - Each plant received $20 \mathrm{ml}$ of $5 \mathrm{mM} \mathrm{CaCl}_{2}$ containing $100 \mathrm{KBq}$ of ${ }^{45} \mathrm{CaCl}_{2}(0.074 \mathrm{GBq} / \mu \mathrm{mol}$, Amersham). The solution was supplied at 8:00a.m. and the 
Uptake and translocation of nitrogen, phosphorus and calcium in soybean...

roots were collected $24 \mathrm{~h}$ later.

The roots of the pot containing vermiculite were removed and discarded. The shoots of the plants were cut and the dry weights $\left(70{ }^{\circ} \mathrm{C}\right)$ were determined. The roots in the upper pot were washed free of soil and dried at $70{ }^{\circ} \mathrm{C}$. The dried material was finely ground in a ball mill for analysis.

\section{Analysis}

Nitrogen - Samples of 0.10 to $0.20 \mathrm{mg}$ of the powdered roots and shoots were transferred to stannic capsules and used to determine total $\mathrm{N}$ and ${ }^{15} \mathrm{~N}$ contents. The determinations were made on the dry samples using the Automated ${ }^{15} \mathrm{~N}{ }^{13} \mathrm{C}$ Analysis - Mass Spectrometry or ANCA-MS system (Barrie \& Prosser, 1996).

Phosphorus - $0.5 \mathrm{~g}$ of the dried material was subjected to nitric-perchloric digestion $(5: 1, \mathrm{v} / \mathrm{v})$. The digested material was diluted to $50 \mathrm{ml}$ with deionised water and total $\mathrm{P}$ was determined colorimetrically using a vanadate-molybdate reagent (Sarruge \& Haag, 1974). The radioactivity was determined in $20 \mathrm{ml}$ of the diluted extract in a Walac 4000 scintillation counter using the Cerenkov effect (Awerbuch \& Avnimelech, 1970).

Calcium - The material used for Ca determination was subjected to nitric-perchloric digestion as above. In $1 \mathrm{ml}$ of the diluted samples, total $\mathrm{Ca}$ was determined by atomic absorption spectrophotometry, after addition of $9.0 \mathrm{ml}$ of lanthanum solution (Sarruge \& Haag, 1974). The radioactivity was determined in $1 \mathrm{ml}$ of the extract after addition of $9 \mathrm{ml}$ of scintillation cocktail and counting in a Wallac 4,000 scintillation counter (Nascimento Filho \& Lobão, 1977).

\section{RESULTS}

\section{Nematode reproduction}

The estimated numbers of nematode eggs in soybean plants 50 days after inoculation showed an increase with increasing inoculum levels (Figure 1). Lower egg production was observed for Meloidogyne javanica in both cultivars. $M$. incognita seemed to reproduce better in 'BR16' but the same was not observed for M. javanica. Although no attempt was made to determine the numbers of root galls, there was an obvious increase in their number with increased inoculum level.

\section{Plant growth, nutrient uptake and translocation}

In general, with increasing inoculum levels of both nematodes there was a tendency for shoot dry mass values to decrease (Figures 2B, E, H), this being more pronounced with the plants of the $\mathrm{Ca}$ experiment. Plant shoot weights in the $\mathrm{N}$ experiment, including the controls, were lighter than those of the other experiments (Figure 2B). Probably this occurred because the $\mathrm{P}$ and $\mathrm{Ca}$ experiments were carried out in October to December and the $\mathrm{N}$ experiment in February - March, being affected by light conditions, although the temperature range was very similar. The same was observed with the root dry weights, although for all experiments it was evident that roots infected with increasing inoculum levels were heavier (Figuress 3C, F and I). The total plant dry mass varied in different ways in each experiment. While there was an increase of plant dry mass in 'BR16' plants of the $\mathrm{N}$ experiment and a general decrease in the $\mathrm{Ca}$ experiment, no alterations were observed in the $\mathrm{P}$ experiment with increasing inoculum levels.

Plants of the $\mathrm{P}$ experiment accumulated more of this element with increasing nematode inoculum, and a similar trend was also observed for $\mathrm{N}$ (Figures $3 \mathrm{~A}$ and $\mathrm{D}$ ). The total amounts of $\mathrm{N}, \mathrm{P}$ and $\mathrm{Ca}$ in the shoot were not significantly affected by the nematodes (Figures 3B, E and H). In contrast to the shoots, higher amounts of the nutrients were observed in infected roots with increasing levels of inoculum than in the non-inoculated controls (Figures 3C, F and I).

The high nutrient contents of roots infected with nematodes seemed to be a simple consequence of the increased root mass, (Figure 2). Thus, the concentrations of each nutrient were calculated in the roots, shoots and total plants (Figure 4). A consistent increase was observed only at the highest inoculum level, of plants of the experiment with $\mathrm{P}$ (Figure 4D). This probably occurred in the P experiment due to the variation observed in the roots (Figure 4F), since the concentrations in shoots remained very similar among inoculum levels, nematodes and cultivars (Figure 4E). Nitrogen concentration did not change in the shoots (Figure 4B), which masked the whole plant data (Figure 4A) and the increase observed in the roots with increasing inoculum levels (Figure 4C).

The data obtained for ${ }^{15} \mathrm{~N}$ (Figures $5 \mathrm{~A}, \mathrm{~B}, \mathrm{C}$ ) were similar to those for total $\mathrm{N}$ (Figures $2 \mathrm{~A}, \mathrm{~B}, \mathrm{C}$ ). There was a tendency for ${ }^{15} \mathrm{~N}$ to decrease in the shoots (Figure 5B) and a clear increase in the roots with increasing inoculum levels (Figure 5C), which was high enough to cause an increase in

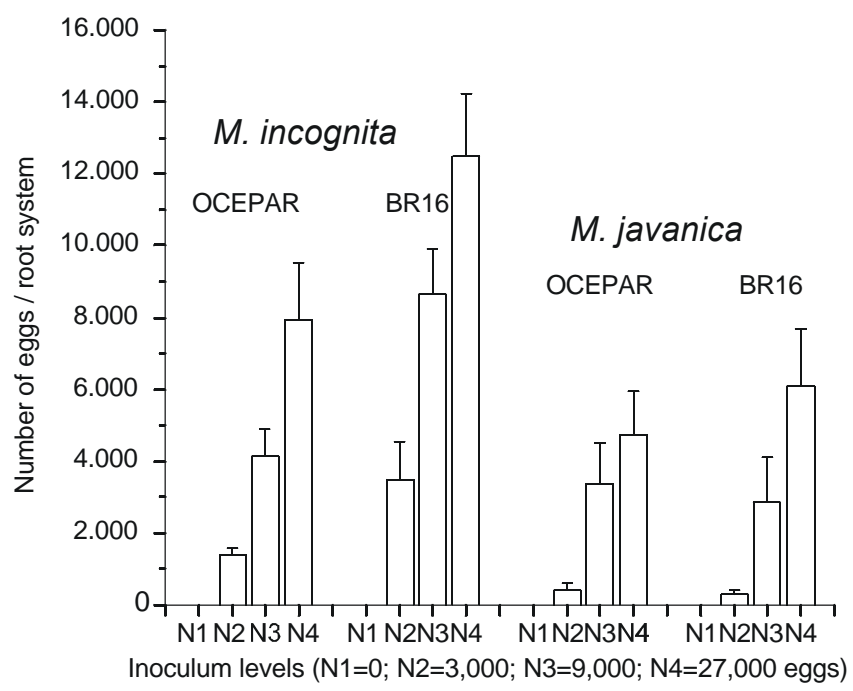

FIG. 1 - Numbers of eggs in the roots of soybean (Glycine max) plants 50 days after inoculation with different inoculum levels of Meloidogyne incognita and $M$. javanica. $\mathrm{N} 1=0 ; \mathrm{N} 2=3000 ; \mathrm{N} 3=9000$ and N4 = 27000 eggs/plant. 
Nitrogen
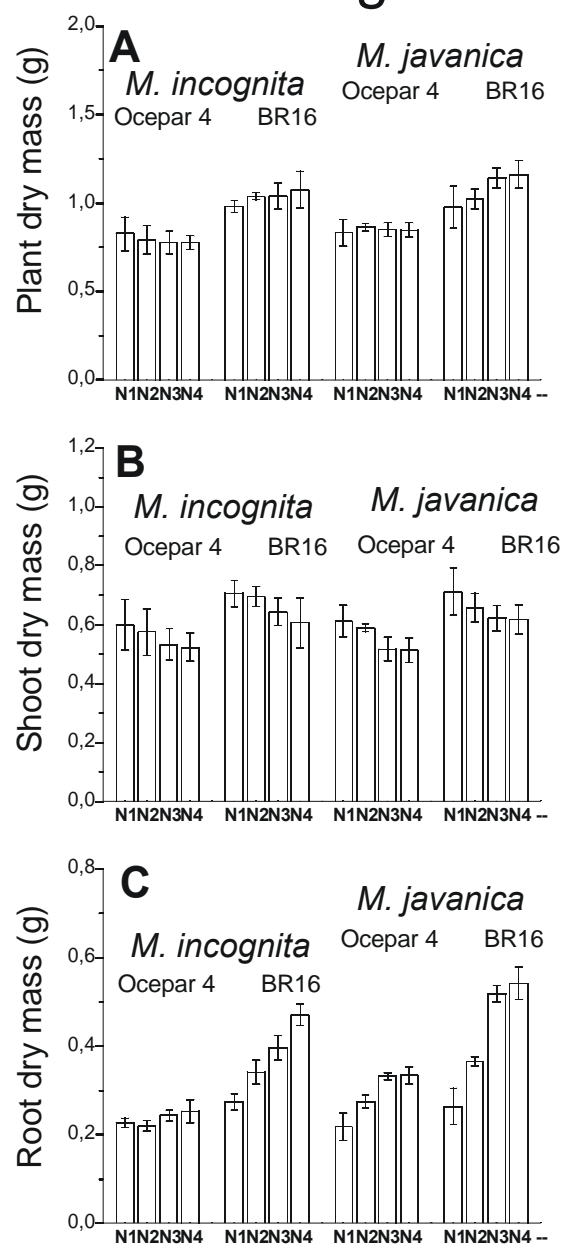

Phosphorus
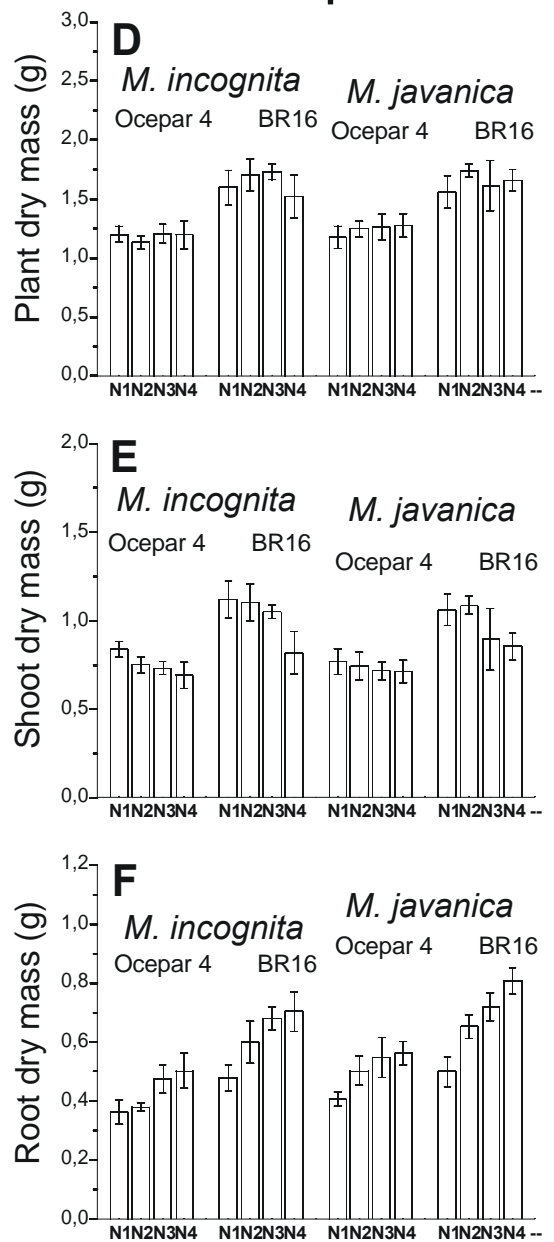

Calcium
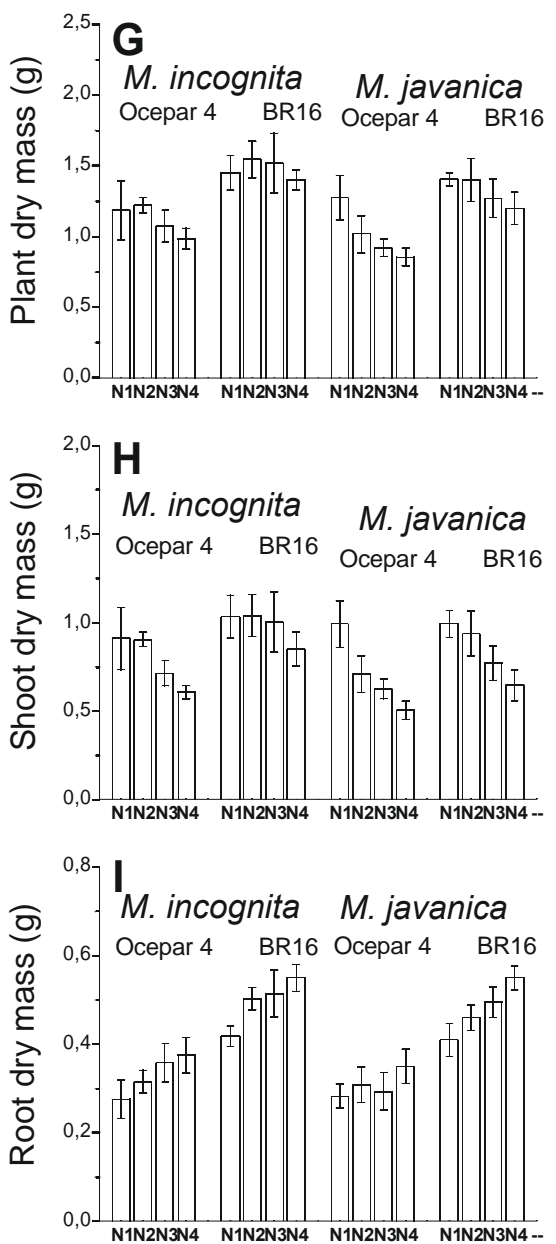

Inoculum levels (N1=0; N2=3,000; N3=9,000; N4=27,000 eggs)

FIG. 2 - Dry weights of whole plants, shoots and roots of soybean (Glycine max) plants infected with different inoculum levels of Meloidogyne incognita and $M$. javanica in the experiments on N, P and Ca uptake. N1 = 0; N2=3 000; N3 $=9000$ and N4 = 27000 eggs/plant.

the whole plants of 'BR16' but not in Ocepar plants (Figure 5A). Although a large variation in the $\mathrm{Ca}$ experiment, the radioactivity in plants fed with ${ }^{32} \mathrm{P}$ (Figure $\left.5 \mathrm{D}\right)$ and ${ }^{45} \mathrm{Ca}(\mathrm{Fi}-$ gure 5G) decreased with increasing inoculum levels, as a consequence of the decrease observed in the shoots (Figures $5 \mathrm{E}, \mathrm{H}$ ) and roots (Figures 5F, I). The relative distribution of the amount of each labelled compound was different between root and shoot. For ${ }^{15} \mathrm{~N}$, most of the nutrient was present in the shoots (Figure 5B). On the other hand, most of the radioactivity of ${ }^{32} \mathrm{P}$ and ${ }^{45} \mathrm{Ca}$ was detected in the roots (Figures $5 \mathrm{~F}, \mathrm{I}$ ).

When the concentrations (specific radioactivity) of the labelled nutrients were calculated, almost no variation was observed with ${ }^{15} \mathrm{~N}$ (Figures 6A, B, C) except an increase with increasing inoculum levels in roots of plants inoculated with $M$. incognita (Figure 6C). Similar to the total radioactivity (Figures 5D-I), there was a reduction of the specific radioactivity with increasing inoculum levels in those plants that received ${ }^{32} \mathrm{P}$ (Figures $6 \mathrm{D}, \mathrm{E}, \mathrm{F}$ ) and ${ }^{45} \mathrm{Ca}$ (Figures $6 \mathrm{G}, \mathrm{H}$,
I). The reduction was more pronounced in the roots than in the shoots.

\section{DISCUSSION}

Although 'Ocepar 4' has been rated as moderately resistant to $M$. incognita race 3 (Embrapa, 1996), nematode reproduction on this cultivar was similar to that observed in the susceptible BR 16. On the other hand, lower egg production was observed in both cultivars when inoculated with $M$. javanica, for which these cultivars have been rated as susceptible. Similar results were found by Carneiro et al. (1999). These discrepancies may be related to the fact that the screening of Brazilian soybean genotypes for root-knot nematode resistance has normally been carried out under field conditions and the host status predominantly rated on a rootgall index basis (EMBRAPA, 1996), instead of an evaluation under controlled conditions and based on nematode 
Uptake and translocation of nitrogen, phosphorus and calcium in soybean...

Nitrogen
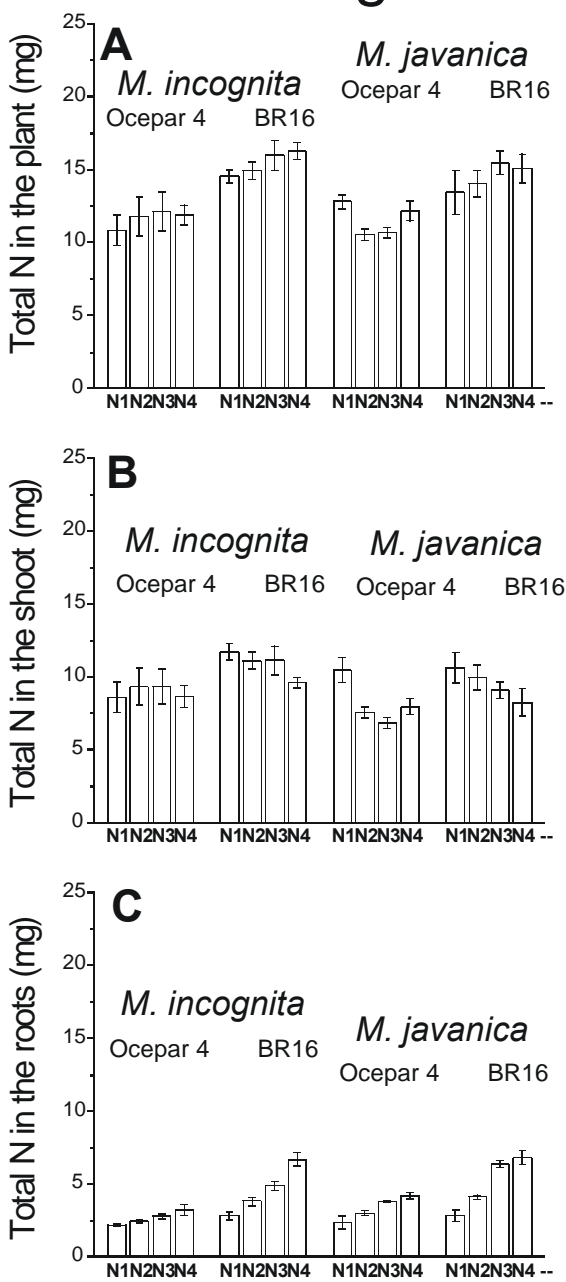

Phosphorus
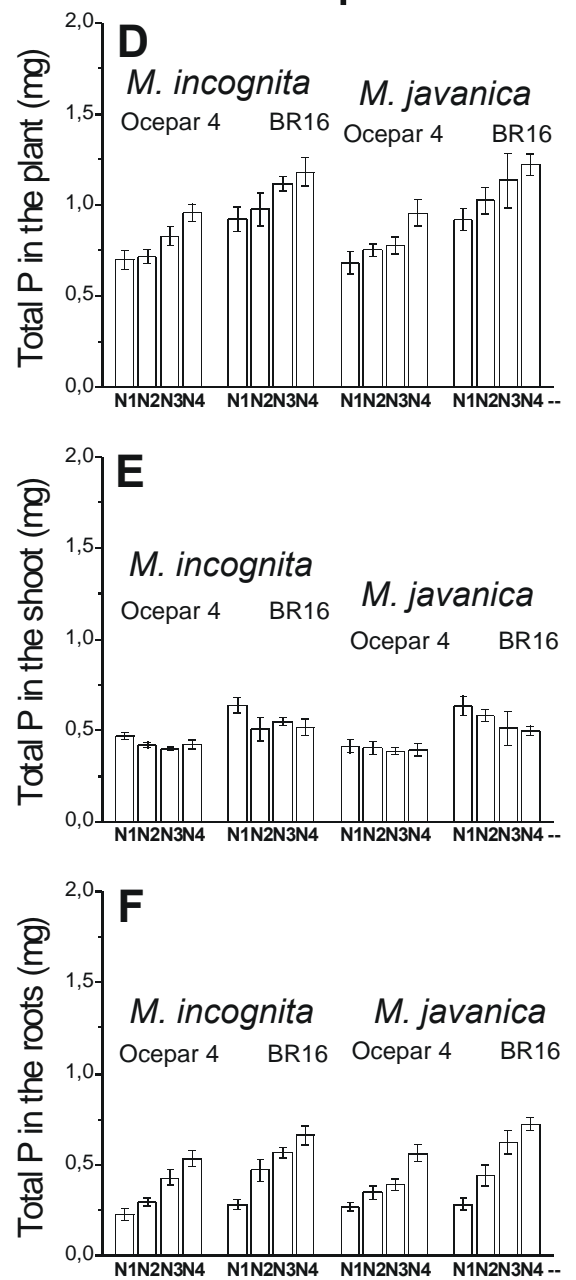

Calcium
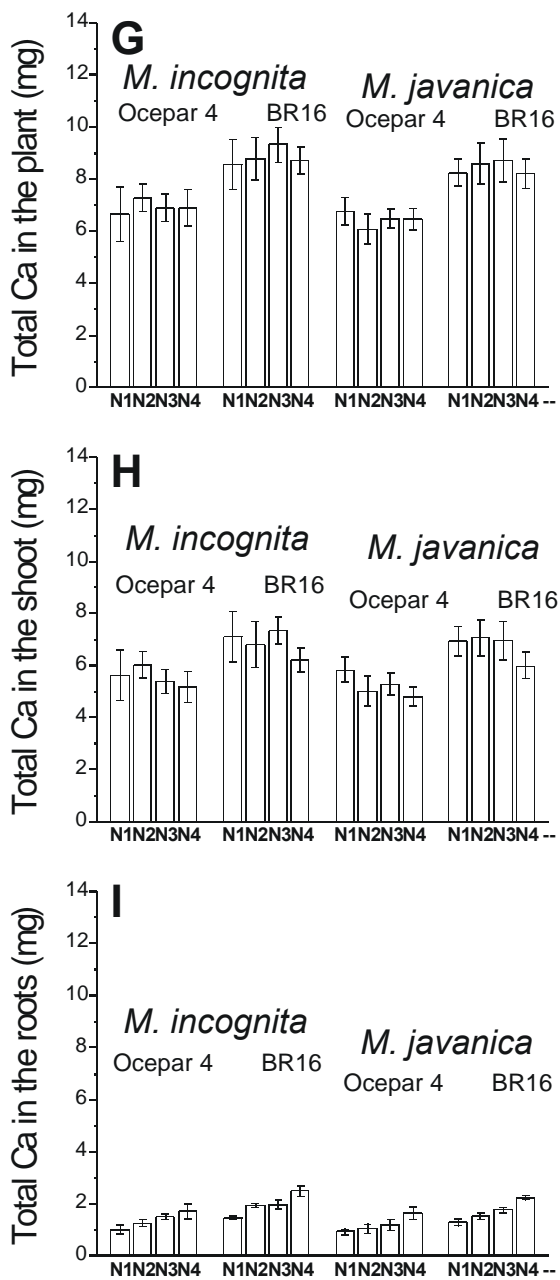

Inoculum levels ( $\mathrm{N} 1=0 ; \mathrm{N} 2=3,000 ; \mathrm{N} 3=9,000 ; \mathrm{N} 4=27,000$ eggs)

FIG. 3 - Total content of N, P and Ca in the plants (root+shoot), shoots and roots of soybean (Glycine max) plants infected with Meloidogyne incognita and M. javanica.

reproductive rate.

Although some variation was observed, mainly in the experiment with ${ }^{15} \mathrm{~N}$, all three experiments showed a trend toward a reduction of shoot weight and an increase of root weight. It is worth mentioning that 'BR16', which showed the best nematode reproduction, had the highest increase of the root mass. Certainly, the root galls contributed to this. Although increase of the mass of root systems infected by root-knot nematodes has been reported (Wallace, 1971; Carneiro et al., 1999), there is no information available concerning the relative contribution of secondary roots and galls. Formation of new secondary roots subsequent to the presence of nematodes was studied by Hutangura et al. (1999), suggesting the participation of increased levels of plant hormones.

The effects of nematodes on carbon partition in soybean in short term experiments, approximately for one nematode life cycle, have been discussed (Carneiro et al., 1999). The decrease in the shoot mass seems to be very closely related to the root growth, and might be a consequence of the strong carbon sink represented by gall formation and the emission of new secondary roots (Oteifa \& Elgindi, 1962; Wallace, 1971; Hutangura et al., 1999). Decrease of photosynthesis in plants infected by nematodes has been observed by several authors (Hussey, 1985; Melakeberhan et al.; 1985). Although photosynthesis was not measured in our study, in the three experiments there were no differences between cultivars in terms of total plant mass, which suggests that net carbon assimilation was similar, and therefore one may assume that the decrease in the shoot mass was a consequence of the preferential carbon distribution to the roots.

Due to their high specific activity, the contribution of the labelled nutrients to the total nutrients in the plants was very low, so the data shown in Figures 3 and 4 can be considered as representative of the endogenous nutrient levels. Since almost 50 days elapsed between sowing and the supply 
Nitrogen
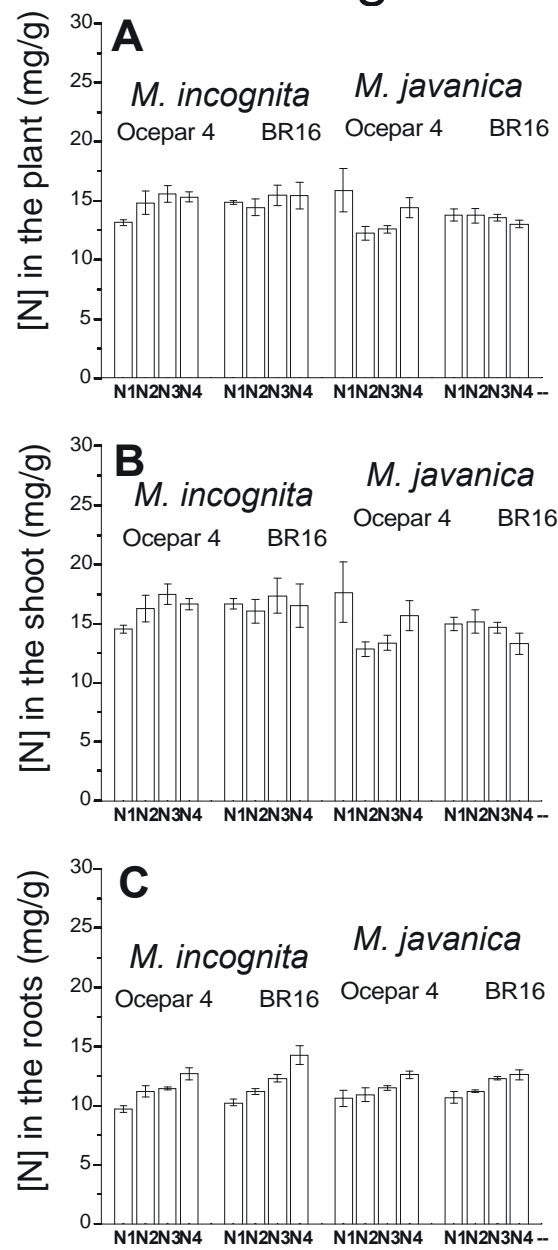

Phosphorus
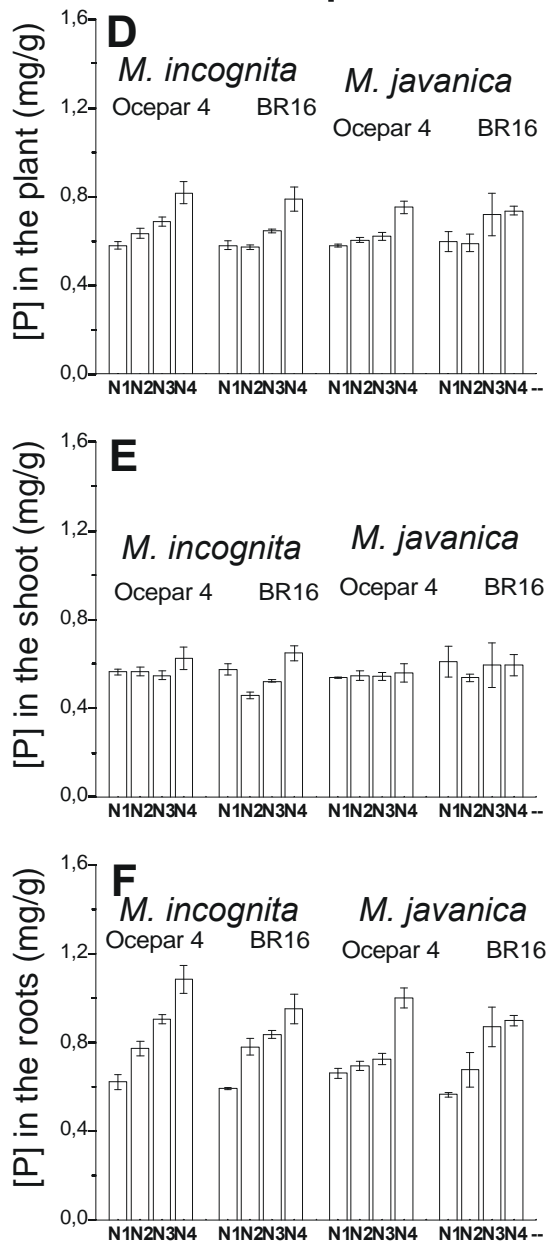

Calcium
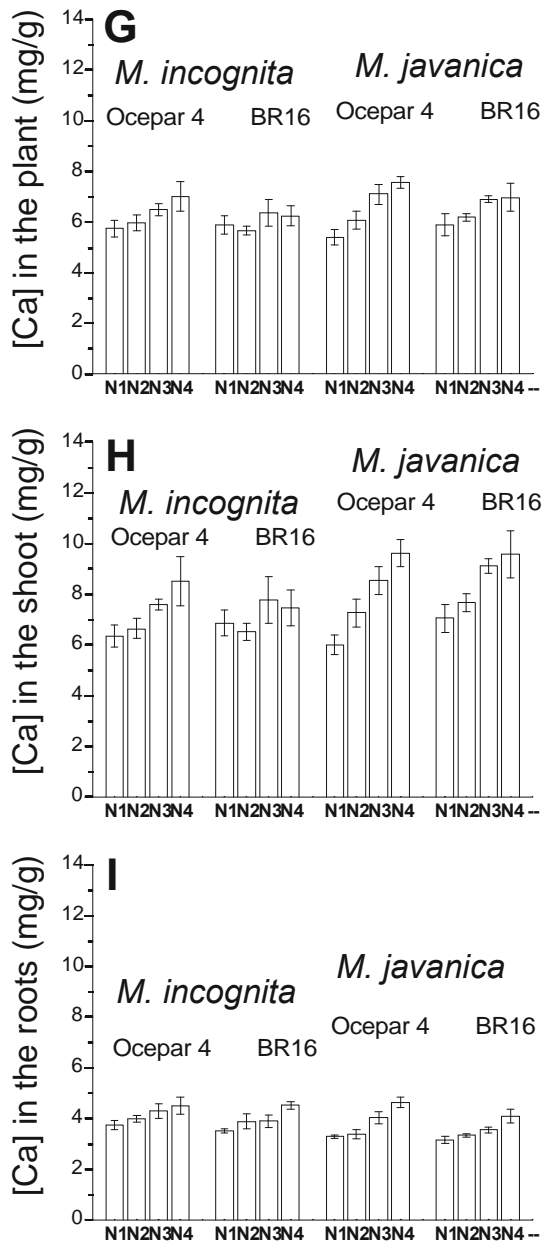

Inoculum levels (N1=0; N2=3,000; N3=9,000; N4=27,000 eggs)

FIG. 4 - Concentrations of $\mathrm{N}, \mathrm{P}$ and $\mathrm{Ca}$ in the plant (root+shoot), shoot and roots of soybean (Glycine max) plants infected with Meloidogyne incognita and M. javanica.

of labelled nutrients, these data reflect what happened during this period, representing cumulative information, and should initially be discussed separately from the data of the labelled nutrients.

Our data show that roots of infected plants accumulated more N, P and $\mathrm{Ca}$ than the uninfected controls. Since the infected roots were heavier than those of the controls, this higher amount of nutrients is probably a consequence of an increased root system absorbing surface, although gall formation would have contributed significantly to the final root mass.

A similar situation was observed in the roots when the data was presented as concentrations of nutrients, i.e. there was an increase in the concentration with increasing inoculum levels. Thus, total amount and concentration data together suggest that infected roots did indeed absorb more nutrients during the 50 days after inoculation. But in contrast to $\mathrm{N}$ and $\mathrm{P}$, whose concentrations did change in the shoots, the infected plants of the experiment with $\mathrm{Ca}$ had higher concentrations of this nutrient in the higher inoculum levels.
We speculate that this result is a consequence of a concentrating effect, due to reduction of the leaf area and maintenance of the $\mathrm{Ca}$ level in the leaves. Initially, before nutrient absorption was affected by nematode parasitism, infected and healthy plants absorbed the same amount of Ca. Later, when nematode infection was affecting several physiological processes, including nutrient absorption, the decrease in shoot weight was such that it caused an artificial increase of the nutrient concentration in the shoot. However, one may argue that the same was not observed with $\mathrm{N}$ and $\mathrm{P}$, and therefore it is more probable that the accumulation of $\mathrm{Ca}$ was due to a greater translocation to the shoot in infected plants instead of a concentrating effect. This higher translocation to the shoot was not evidenced by the data of total amount in the plant, probably because it was masked by a significant reduction in the shoot.

Melakeberhan et al. (1985) studied the uptake and translocation of several nutrients, including $\mathrm{Ca}$, in common bean plants infected with different inoculum levels of $M$. 
Uptake and translocation of nitrogen, phosphorus and calcium in soybean...

Nitrogen
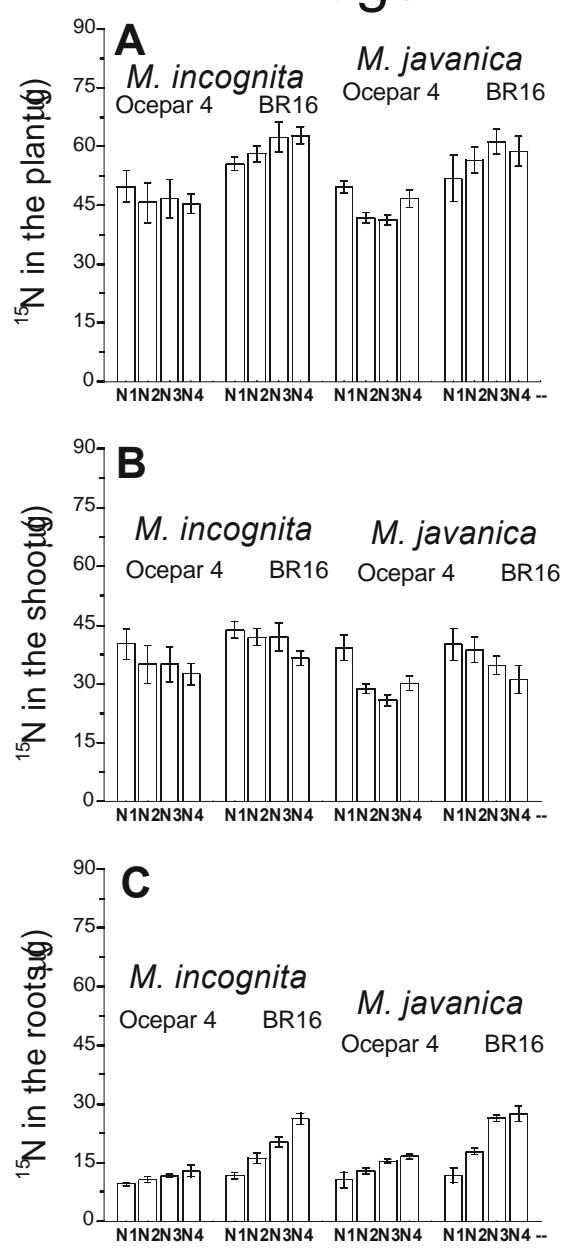

Phosphorus
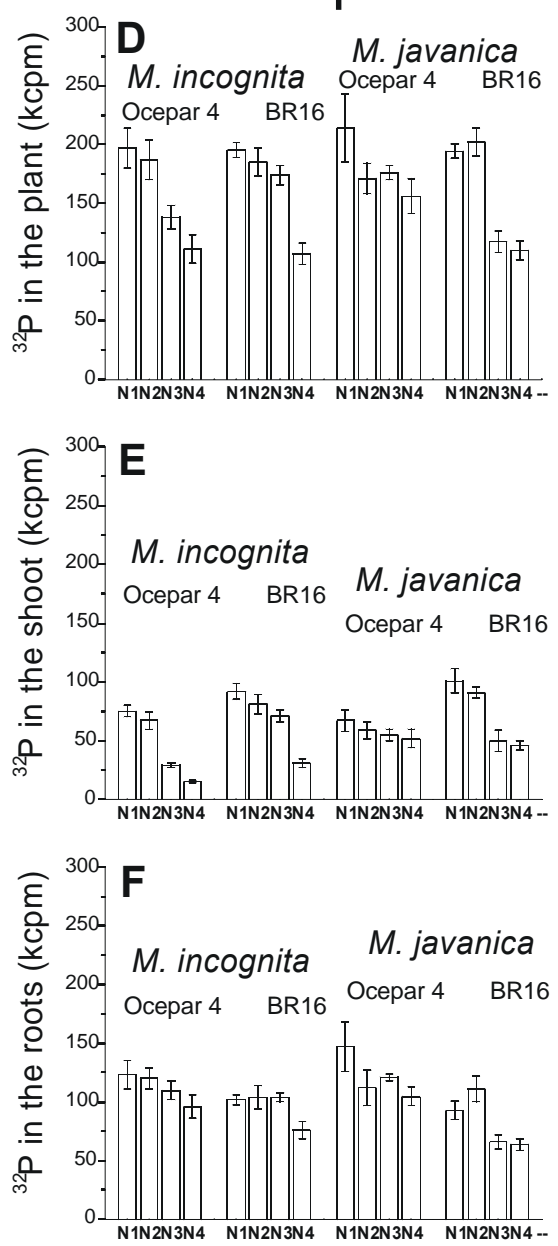

Calcium
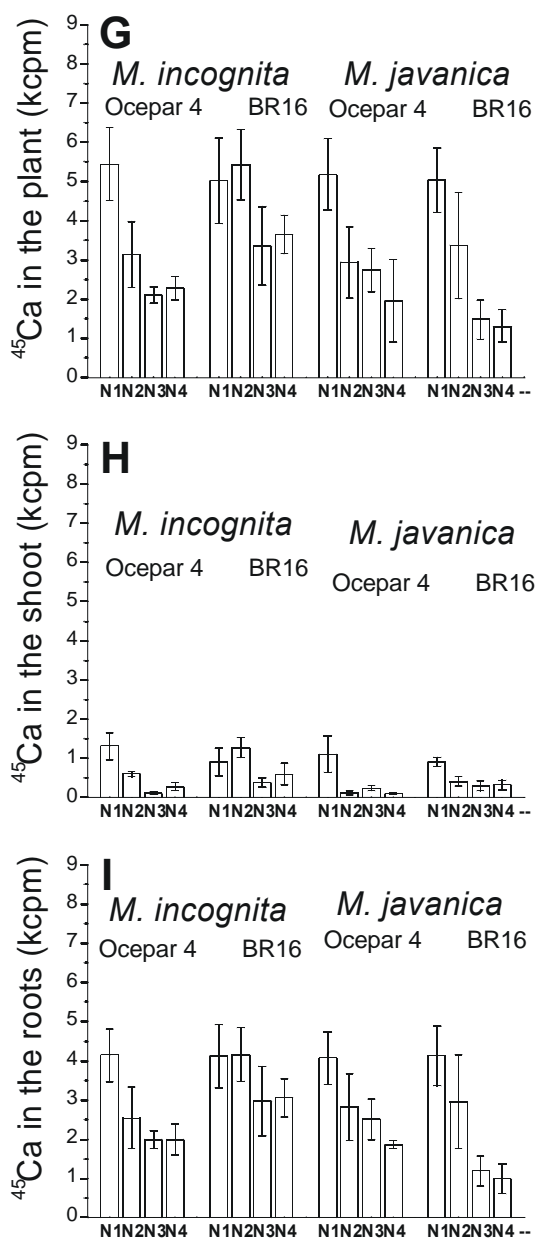

Inoculum levels ( $\mathrm{N} 1=0 ; \mathrm{N} 2=3,000 ; \mathrm{N} 3=9,000 ; \mathrm{N} 4=27,000$ eggs)

FIG. 5 - Total contents of ${ }^{15} \mathrm{~N}$ (abundance), $P$ and Ca (radioactivity) in plants (root+shoot), shoot and roots of soybean (Glycine max) plants infected with Meloidogyne incognita and M. javanica.

incognita, 21 days after inoculation. They observed that a reduction in the shoot dry weight was associated with an increase of the Ca concentration in the leaves with increasing inoculum levels, although infected plants had absorbed less than healthy plants. However, infected plants showed proportionally more $\mathrm{Ca}$ in the shoots than in the roots. The authors concluded that the lower Ca content of infected plants was a consequence of the lower dry weight, which caused a higher concentration in the leaves, and that translocation of Ca to the shoot was not affected.

Together with the production of new secondary roots (to increase the absorbing surface), the blockage of xylem vessels (caused by continuous nematode body enlargement up to maturity - most importantly in adult females) and the action of nematodes as nutrient sinks, are the reasons for nutrient accumulation in the roots. Several histological reports showed that in roots infected by Meloidogyne there is an obstruction of the xylem as well as formation of non functional vessels in the surrounding areas of the galls and giant cells
(Dorhout et al., 1991; Kirkpatrick et al., 1991). Thus, nutrient transport could be affected by a decrease of water transport. Dorhout et al. (1988) used the dye Tinopal CBS to study water movement in the xylem of tomato roots infected with M. incognita. They observed that the dye leaked out of the xylem vessels close to the giant cells, remaining in the apoplast of the galls. They also observed that the water did not flow from the cortex to the stele along the nematode body, or from the stele to the cortex. Therefore, nutrients would also be retained in the roots.

The accumulation of nutrients in the infected roots might also be a response to nematodes as metabolic sinks. Besides N, which is a component of proteins, $\mathrm{P}$ is necessary for the synthesis of ATP, is a component of membranes, participates in carbohydrate breakdown during respiration, etc (Mengel \& Kirkby, 1987). Dropkin \& King (1956) supplied $\mathrm{H}_{3}{ }^{32} \mathrm{PO}_{4}$ to tomato plants infected with $M$. incognita 25 days after inoculation, and observed significant accumulation of radioactivity mainly in adult females when compared with 

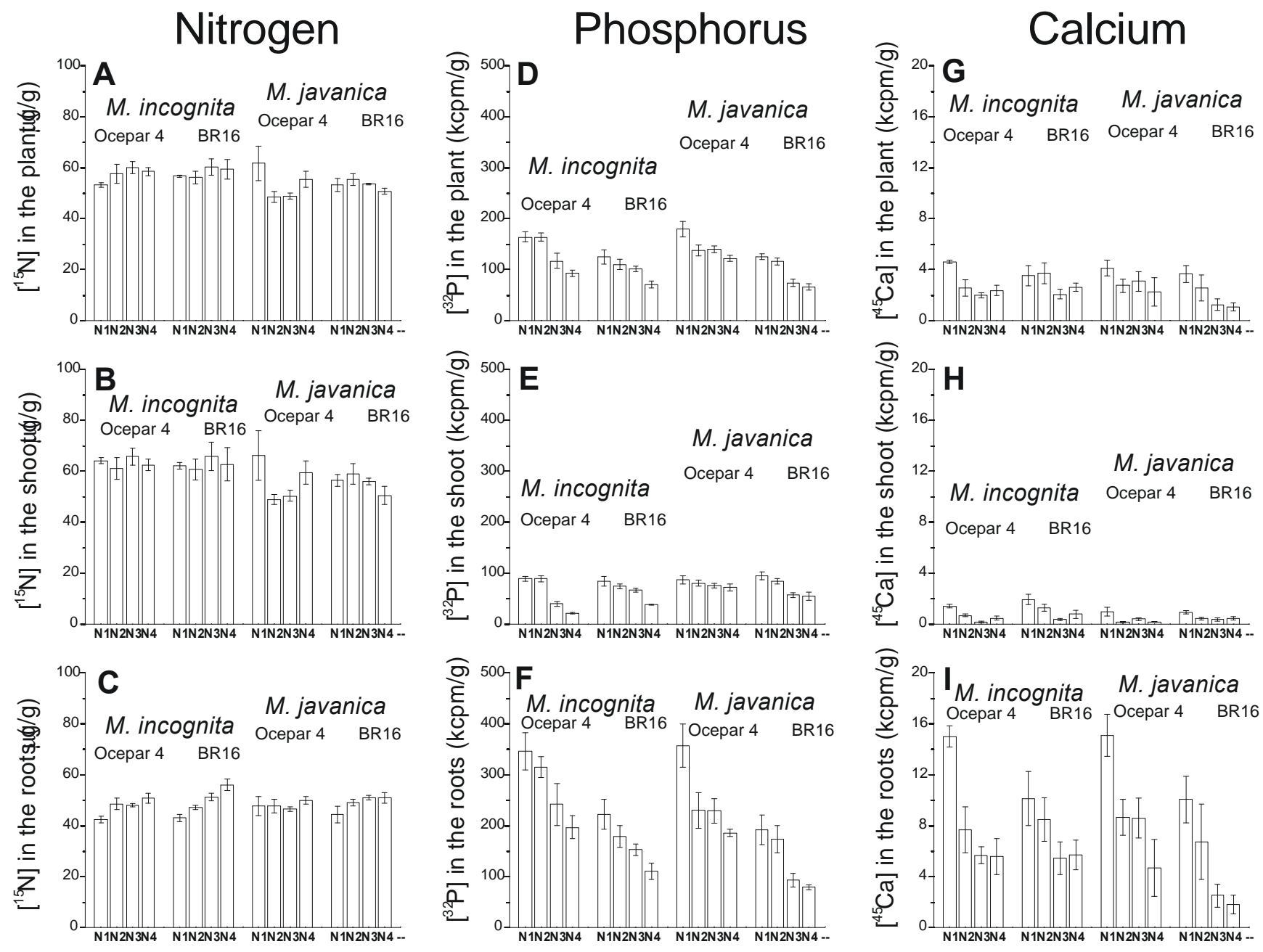

Inoculum levels (N1=0; N2=3,000; N3=9,000; N4=27,000 eggs)

FIG. 6 - Concentration of $\mathbf{N}$ (abundance/g), $\mathbf{P}$ and Ca (radioactivity/g) in plants (root+shoot), shoots and roots of soybean (Glycine max) plants infected with Meloidogyne incognita and M. javanica.

other larval stages of the nematode. Autoradiography of plants fed with ${ }^{32} \mathrm{P}$ was also used in the present work and strong labelling in galls was observed (data not shown).

The data obtained after feeding the plants with labelled nutrients reflect a situation in which the nematodes were already established in the plant tissue and probably had completed a life cycle. Thus, in contrast to total contents, which represent cumulative data, the labelled nutrient data shows events at a specific time of infection.

While total and specific radioactivity of ${ }^{32} \mathrm{P}$ and ${ }^{45} \mathrm{Ca}$ decreased in the roots at high inoculum levels, the opposite was observed for ${ }^{15} \mathrm{~N}$. The data on ${ }^{15} \mathrm{~N}$ were very similar to total $\mathrm{N}$ determinations, but, since these data represent a specific moment of the infection, the increase in ${ }^{15} \mathrm{~N}$ concentration would indicate that the infected roots took up more $\mathrm{N}$ and that translocation to the shoot was not affected since concentration did not change.

The data on the influence of nematodes on $\mathrm{N}$ uptake by plants are controversial. Some reports detected an increase of $\mathrm{N}$ in the roots but no alteration in the shoots (Hunter, 1958; Shafiee \& Jenkins, 1963) while others showed that there was no alteration in the roots and shoots (Melakeberhan et al., 1985; Gonçalves et al., 1995). However, none of these reports dealt with $\mathrm{N}$ absorption by using a split root system or carried out short term experiments as done here.

In contrast to the total determinations, the data obtained for ${ }^{32} \mathrm{P}$ and ${ }^{45} \mathrm{Ca}$ showed a reduction of specific and total radioactivity in the roots with increasing inoculum levels. In addition, low radioactivity in the roots was clearly associated with low radioactivity in the shoots, indicating that, besides nutrient uptake, nematodes interfered with translocation to the leaves. However, there were no significant alterations in the shoot concentrations of $\mathrm{P}$, or in the total contents of $\mathrm{Ca}$ and $\mathrm{P}$ with increasing inoculum levels. Based on these data it was suggested above that $\mathrm{Ca}$ accumulated in the leaves because of higher translocation. The radioactivity data showed the contrary. Therefore, as also suggested above, total nutrient estimations and labelled nutrient data represent 
Uptake and translocation of nitrogen, phosphorus and calcium in soybean...

two different situations that, depending on the nutrient, may be coincident (as observed for $\mathrm{N}$ ) or not.

The P data showed an intermediate situation. In the roots, the endogenous and isotopic data were contrary, i.e. there was an increase in the overall nutrient content with increasing inoculum levels in the roots, but a clear decrease in the isotopic concentrations. On the other hand, the total contents of shoots did not vary significantly, while the ${ }^{32} \mathrm{P}$ data showed an obvious decrease in the higher inoculum levels.

Oteifa \& Elgindi (1962) studied the absorption of ${ }^{32} \mathrm{P}$ in tomato plants infected with $M$. javanica at different times after inoculation. There was a greater accumulation of radioactivity after 30 days and a reduction was observed at 60 and 90 days; however, less radioactivity was detected in the shoots of infected plants in the three periods of analysis. Although total $\mathrm{P}$ in plants had increased at 30 days, the opposite occurred at 60 and 90 days. According to these authors, production of new secondary roots was estimulated in the initial period of infection, thereby explaining the higher absorption of ${ }^{32} \mathrm{P}$ at 30 days. Later, these new roots were also infected, and this affected absorption of the nutrient.

Dropkin \& King (1956) observed that infection of some root segments did not affect absorption of $\mathrm{P}$ in other segments of the same root system in tomato plants infected with $M$. incognita. In our study, before supplying the labelled nutrients, the root systems absorbed nutrients from the upper pot, containing as substrate a mixture of soil and sand. Therefore, the total nutrient data presented here are comparable to several reports in the literature, where nutrients were simply analysed in plants at a given time after inoculation. On the other hand, the way that the labeled nutrients were supplied differentiates this work from others, since, according to the methodology adopted here, the galls were positioned between healthy roots and the shoot. Thus, the barrier that galls may represent to the natural flow of nutrients from the roots to the shoot could be studied as well as the effect of nematode infection on the absorption of nutrients far from the infection sites. According to our results, in addition to other problems caused by nematode infection, such as decrease of water flow due to a reduced leaf area, we may conclude that in some way nematodes also cause physiological disorders in root segments located far from the infection site. This probably is much influenced by galls acting as strong metabolic sinks. Here, we have reported variations among nutrients, but some of this variation may be related to the fact that some nutrients are more mobile inside the plants than others. According to Mengel \& Kirkby (1987) Ca is poorly translocated, in contrast to $\mathrm{P}$ and $\mathrm{N}$, the latter being apparently the most reused nutrient in the plant. Since nematodes are such strong sinks, some return of nutrients to the infected roots is possible, and this would affect the data on total nutrient content.

\section{ACKNOWLEDGEMENTS}

This work was granted by Fundação de Amparo à Pesquisa do Estado de São Paulo - FAPESP (Proc. 97/03961-7).
R.G.C., P.M., L.C.C.B.F thanks to CNPq - Brazil for research fellowships. The authors also wish to thank the Dulce Regina Joaquim and Denise Silva for their excellent technical assistance.

\section{LITERATURE CITED}

AWERBUCH, T. \& AVNIMELECH, Y. Counting ${ }^{32} \mathrm{P}$ in plant tissues using Cerenkov effect. Plant Soil 33:260-264. 1970.

BARRIE, A. \& PROSSER, S.J. Automated analysis of light-element stable isotopes by isotope ratio mass spectrometry. In: Boutton, T.W. \& Yamasaki, S. (Eds.) Mass Spectrometry of Soils. San Diego. Academic Press. 1996. pp.1-46.

BERGESON, G.B. Mobilization of minerals to the infection site of root knot nematodes. Phytopathology 56:1287-1289. 1966.

BONETI, J.I.S. \& FERRAZ, S. Modificação do método de Hussey \& Barker para extração de ovos de Meloidogyne exigua de raízes de cafeeiro. Fitopatologia Brasileira 6:553. 1981.

CARNEIRO, R.G., MAZZAFERA, P. \& FERRAZ, L.C.C.B. Carbon partitioning in soybean infected with Meloidogyne incognita and $M$. javanica. Journal of Nematology 31:348-355. 1999.

DORHOUT, R., GOMMERS, F.J. \& KOLLOFFEL, C. Water transport through tomato roots infected with Meloidogyne incognita. Phytopathology 81:379-385. 1991.

DORHOUT, R., KOLLOFFEL, C. \& GOMMERS, F.J. Transport of an apoplastic fluorescent dye to feeding sites induced in tomato roots by Meloidogyne incognita. Phytopathology 78:14211424. 1988.

DROPKIN, V.H. \& KING, R.C. Studies on plant parasitic nematodes homogeneously labeled with radiophosphorus. Experimental Parasitology 5:469-480. 1956.

EMBRAPA - Empresa Brasileira de Pesquisa Agropecuária. Centro Nacional de Pesquisa de Soja. Recomendações técnicas para a cultura da soja na região central do Brasil 1996/97. Londrina, EMBRAPA. CNPSo. Documentos, 96. 1996.

GONÇALVES, W., MAZZAFERA, P., FERRAZ, L.C.C.B., SILVAROLLA, M.B. \& LIMA, M.M.A. Biochemical basis of coffee tree resistance to Meloidogyne incognita. Plantations Recherche Développement 2:54-58. 1995.

HOAGLAND, D.R. \& ARNON, D.I. The water-culture method for growing plants without soil. Berkeley. California Experimental Agriculture Station. Circular 347. 1950.

HUNTER, A.H. Nutrient absorption and translocation of phosphorus as influenced by the root knot nematode (Meloidogyne incognita acrita). Soil Science 86:245-250. 1958.

HUSSEY, R.S. Host-parasite relationships and associated physiological changes. In: Sasser, J.N. \& Carter, C.C. (Eds) An Advanced Treatise on Meloidogyne: biology and control. Raleigh. North Carolina State University Press. 1985. pp.143153.

HUSSEY, R.S. \& BARKER, K.R. A comparison of methods of collecting inocula of Meloidogyne spp., including a new technique. Plant Disease Reporter 57:1025-1028. 1973.

HUTANGURA, P., MATHESIUS, U., JONES, M.G.K. \& ROLFE, B.G. Auxin induction is a trigger for root gall formation caused by root-knot nematodes in white clover and is associated with the activation of the flavonoid pathway. Australian Journal of Plant Physiology 26:221-231. 1999.

JENKINS, W.R. \& MALEK, R.B. Influence of nematodes on absorption and accumulation of nutrients in vetch. Soil Science 101:46-49. 1966. 
KIRKPATRICK, T.L., OOSTERHUIS, D.M. \& WULLSCHLEGER, S.D. Interaction of Meloidogyne incognita and water stress in two cotton cultivars. Journal of Nematology 23:462-467. 1991.

MELAKEBERHAN, H., WEBSTER, J.M. \& BROOKE, R.C. Response of Phaseolus vulgaris to a single generation of Meloidogyne incognita.. Nematologica 31:191-202. 1985.

MENGEL, K. \& KIRBY, E.A. Principles of plant nutrition. $4^{\text {th }}$ ed. Bern. International Potash Institute. 1987.

NASCIMENTO FILHO, U.F. \& LOBÃO, A.O. Detecção de P-32 em amostras de origem animal e vegetal por efeito Cerenkov, cintilação líquida e detector GM. Boletim Científico CENA
48:1-25. 1977.

OTEIFA, B.A. \& ELGINDI, D.M. Influence of parasitic duration of Meloidogyne javanica (Treub) on host nutrient uptake. Nematologica 8:216-220. 1962.

SARRUGE, J.R. \& HAAG, H.P. Análises químicas em plantas. Piracicaba, University of São Paulo - ESALQ, 1974.

SHAFIEE, M.F. \& JENKINS, W.R. Host-parasite relationships of Capsicum frutescens and Pratylenchus penetrans, Meloidogyne incognita acrita, and M. hapla. Phytopathology 53:325-328. 1963.

WALLACE, H.R. The influence of density of nematode populations on plants. Nematologica 17:154-166. 1971. 